\title{
Does Sourgrass leaf anatomy influence glyphosate resistance?
}

\author{
Arthur Arrobas Martins Barroso*1, Esteban Galeano², Alfredo Junior Paiola Albrecht ${ }^{3}$, \\ Fabrícia Cristina dos Reis ${ }^{2}$, Ricardo Victoria Filho² \\ 'Universidade Estadual Paulista, Jaboticabal, SP, Brasi \\ ${ }^{2}$ Universidade de São Paulo, São Paulo, SP, Brasil \\ ${ }^{3}$ Universidade Federal do Paraná, Palotina, PR, Brasi \\ *Autor correspondente, e-mail: arthuragro07@hotmail.com
}

\begin{abstract}
Sourgrass(Digitaria insularis, L. Mez ex Ekman)is a weed that requires high rates of glyphosate ((N-[phosphonomethyl]-glycine) forcontrol, verylittle of the herbicide applied isabsorbed by theleaves. Morphological and histological differences in leaves of glyphosate-resistant and glyphosate-susceptible plantsshould explain the contrast of variance between herbicide susceptibility. Leaves of different growth andphenological stages were collected and submitted to histological andelectron microscopy scanning analysis. Those plants were also submitted to a glyphosate dose-response curve analysis. The results suggest thatbiotypes exhibits differences infoliar structures that can influence the uptake and translocation of glyphosate. A thinparenchyma, lesser distance amongvascular bundles, and higher phloem sizewere found in resistant biotypes (differences close to 10\%). Minor stomata number and higher epicuticular waxy deposition in stomata and leaf surface were found in resistant plants when leaves came from regrowth, leading to a possiblelesser herbicide absorption. Resistant plants showed absence of trichomes in late stages of development ( $64 \%$ less trichomes than susceptible plants). The higher concentration of trichomes in susceptible plants can be an absorption pathfor glyphosate getthrough the cuticle.
\end{abstract}

Keywords: Absorption, herbicide resistance, parenchyma, trichomes

\section{A anatomia foliar de capim-amargoso influencia na resistência ao glyphosate?}

\section{Resumo}

O capim-amargoso (Digitaria insularis, L. Mez ex Ekman) é uma plantadaninha que requer altas dosesde glifosato (( $\mathrm{N}$ - [fosfonometilo] glicina) para seu controle, sendo pouco do herbicida aplicado absorvido pelas folhas. Diferenças morfológicas e histológicas em folhas de biótipos resistentes e suscetíveis ao glifosato podem explicar a susceptibilidade diferencial ao herbicida. Folhas de diferentes estádios de crescimento de plantas foram coletadas e submetidas à análise histológica e de microscopia eletrônica de varredura. Essas plantas foram também submetidas a uma curva de dose-resposta ao glifosato. Os resultados sugerem diferenças foliares que podem influenciar a absorção e translocação de glyphosate. Um parênquima menos espesso, menores distâncias entre feixes vasculares, e maior tamanho de floema no biótipo resistente em relação ao biótipo suscetível foram observados (diferenças próximo a 10\%). Menor número de estômatos e maior deposição de cera epicuticular em estômatos e superfície foliar nos biótipos resistentes foram encontradas quando a folha veio do rebrote, levando a uma possível menor absorção do herbicida. Em biótipos resistentes encontrou-se aausência de tricomas nos últimos estágios do desenvolvimento $164 \%$ a menos do que os tricomas plantas suscetíveis). A maior concentração de tricomas em plantas sensíveis, podem ser uma via de absorção para o glyphosate por entre a cutícula.

Palavras-chave: Resistência a herbicidas, absorção, tricomas, parênquima 


\section{Introduction}

Glyphosate tolerance has been a key topic ever since some weeds were reported as tolerant to various herbicides (Cruz-Hipolito et al., 2011). Between weeds commonly found in agricultural areas in Brazil, Digitaria insularis (L.) Mez ex Ekman occupies a prominent position by requiring higher glyphosate dosage application for control and because the existence of resistant biotypes (Carvalho et al., 2011). It is an aggressive plant, that can cause losses in crops development, as observed in coffee (Carvalho et al., 2013).

The herbicide efficacy of glyphosate, is dependent of processes such as molecule retention on leaf surfaces, foliar penetration, herbicide translocation to the action site and enolpyruvylshikimate-3-phosphate synthase (EPSPS) inhibition (Satichivi et al., 2000). Leaf morphology modifies retention whereas its anatomy regulates the absorption speed (Procópio et al., 2003). with o as an increase of leaves waxes, the size of individual spray drop deposits on the leaf decreases, resulting in reduced coverage (Hess \& Falk, 1990).

Unfortunately, there is lack of studies demonstrating the influence of leaf structures in resistant biotypes to glyphosate. Glyphosate absorption in different populations ofD. insularis plants was slower in the resistant biotype. According to the researches, the mechanisms affecting the initial absorption of the herbicide in the resistant biotype are unknown (Carvalho et al., 2012).

Inryegrass (Lolium multiflorum) plants withleaf differences may contribute to glyphosate sensitivity (Galvani et al., 2012).Similarly, foliar absorption is one of the mechanisms to glyphosate resistance in Sorghum halepense, both by the leaf retention as slower absorption rate (Vila-Aiub et al., 2011 ).

The differential uptake of glyphosate, the composition of epicuticular wax, leaf angle and various other factors may play a important role in herbicide tolerance in some weeds and as variation in susceptibility of weed species to glyphosate has been observed in the last few years, the better understanding of mechanism underlying such phenomenon is essential (Cruz-
Hipolito et al., 2011, Singh et al., 2011). The objective of this study was to evaluate different leaf structures in glyphosate-resistant and susceptible plants ofD. insularis.

\section{Material and Methods}

\section{Resistance Confirmation}

D. insularis seeds of two biotypes, resistant and susceptible (designated as "R" and "S", respectively) were collected in agricultural fields, such as citrus plantations (2136'42.15"s; $48^{\circ} 26^{\prime} 38.93^{\prime \prime} W$, Resistant) and horticultural areas (2330'30.14"S; 4809'49.28"W, Susceptible), in São Paulo State, Brazil. The resistant seeds were collected from same populations of previous studies of proved glyphosate resistance (Carvalho et al., 2001; Carvalho et al., 2012). Plants with four expanded leaves were sprayed with glyphosate (Roundup Original, $360 \mathrm{gL}^{-1}$, Monsanto, São José dos Campos, Brazil)at seven different doses 10 , 240, 480, 960, 1920, 3840 and $7680 \mathrm{~g} \mathrm{ea} \mathrm{ha}^{-1}$ ) with 5 replicates. Experimental design was completely randomized. Application was developed in a chamber regulated to distribute $200 \mathrm{~L} \mathrm{ha}^{-1}$ of the herbicide, using $275 \mathrm{kPa}$ of pressure and flat spray nozzles (8002, Jacto, São Paulo, Brazil).

At 21 days after application(DAA), the shoot fresh biomassof the plant was measured and expressed as a reduction percentage compared to the control. Data obtained was analyzed using a non-linear regression model with R program, "drc" package (drc 1.2, Christian Ritz and Jens Strebig, R.2.5, Kurt Hornik, online) ( $R$ statistical software, R Foundation for Statistical Computing, Vienna, Austria; https:// www.R-project.org) (Knezevic et al., 2007). The dose-response curve was constructed using a 4-parameter logistic regression following the equation $Y=c+\left\{(d-c)\left[1+(x / g)^{b}\right]\right\}$, where $Y$ is the shoot fresh biomass expressed as a percentage of nontreated control; $c$ and $d$ are the coefficients corresponding to the lower and upper asymptotes; $b$ is the slope of the line; $g$ is the herbicide rate at the point of inflection halfway between the upper and lower asymptotes; and $x$ is the herbicide rate used. Resistance factor (RF) was obtained dividing the $\mathrm{GR}_{50}$ value (dose required to reduce shoot fresh biomass by $50 \%$ 
related to untreated plants) of the resistant biotype by the $\mathrm{GR}_{50}$ value of the susceptible one.

\section{Histological Analysis}

Plants generated from seeds used in the experiment described previously (from both biotypes) were sown in pots inside a greenhouse under conditions of $35 / 25^{\circ} \mathrm{C}$ day/ night temperature and 14-h photoperiod. Pots were watered daily to the field capacity. The fourth leaf of each biotype was collected and cut in its central region to $25 \mathrm{~mm}^{2}$ approximately. Samples were immediately fixed in a modified "Karnovsky" solutionfor 24 hours, using $1.5 \mathrm{ml}$ Eppendorff tubes, keeping them at $4^{\circ} \mathrm{C}$ after being subjected to a vacuum. Then, samples were dehydrated with ethanol and embedded in a mixture of histological paraffin and wax in a proportion of $8: 1 \mathrm{v} / \mathrm{v}$, respectively. Blocks with samples were cut into transverse sections of 5-10 $\mathrm{mm}$ width using a rotary microtome and stained with toluidine blue $(0.05 \%), \mathrm{pH} 2.6$. Subsequently, histological laminas were prepared with synthetic resin (Entellan®), Merck Millipore International, Germany), analyzed and photomicrographed under light microscope (Axioskop 2, Carl Zeiss, USA) being theimages captured with an attached camera (MRC) and with the use of Axiovision program. The parameters evaluated were leaf blade width and epidermis width of the adaxial and abaxial phase. Distance between vascular bundles and the proportion between xylem and phloem were estimated. Analysis of variance (ANOVA) was performed with 30 replicatesfor each variable (SAS/STAT® Software), each cutting microtome was observed twice and 20 cuts were prepared for each treatment resulting from the observation of at least four laminas from four different plants.

\section{Morphological Analysis}

The fourth leaf and pre-inflorescence leaf ( $^{\text {th }}$ leaf) from plantswere collected from each biotype for scanning analysis. For each stage collected, the two surfaces of each biotype (adaxial and abaxial) were observed. For each biotype, leaves were collected and sectioned in its central region to $30 \mathrm{~mm}^{2}$. Samples were processed the same as in the histological analysis but with acetone dehydration. Then, samples were located in individual cages properly identified and placed in a Balzers CPO 050 sputter (Balzers, USA) for drying up to critical point using $\mathrm{CO}_{2}$. Dried samples were attached to stubs and taken to a MED 010 sputter (Balzers, USA) and covered with a gold thin layer $(30-40 \mathrm{~nm})$. After these processes, samples were observed in the scanning electron microscope LEO 435VP using $20 \mathrm{kV}$ (SemTechSolutions, USA). Stomatal index, stomatal density, and trichomes density were analyzed for adaxial and abaxial surfaces of each biotype. Stomatal number, epidermal cells, and trichomes were measured in areas of $0.05 \mathrm{~mm}^{2}$, with 10 replicationsfor each treatment. Quantitative data were subjected to analysis of variance (SAS/STAT® Software). Stomatal index calculation was performed according to the formula Stomatal index $(S I)=N E /(E C+N E) * 100$, where NE is the number of stomata and EC the number of epidermal cells.

\section{Results and Discussion}

\section{Resistance Confirmation}

For regression analysis, shoot fresh biomass data collected at 21 DAA were usedbeing the curvesuitable for the data ( $P$ $<0.05)$. Using the calculated parameters and comparing the $\mathrm{GR}_{50}$ values of the two biotypes, a value of 2.36 for the resistance factor (RF) was reached. This indicates that the resistant biotype of $D$. insularis required a dose 2.36 times higher compared to the dose required to reduce by $50 \%$ the shoot fresh biomass of the susceptible population (Figure 1).

These data corroborate other results observed for the species, ranging the RF from0.50 to 5.6 (Correia et al.,, 2010; Carvalho et al., 2011).

Vascular Bundle, Parenchyma and Xylem/ Phloem Relation

Although the thickness of the adaxial and abaxial surfaces of the leaves was similar for both biotypes (data not shown), the parenchymal thickness had a statistical difference for resistant and susceptible D. insularis plants (Table 1). 


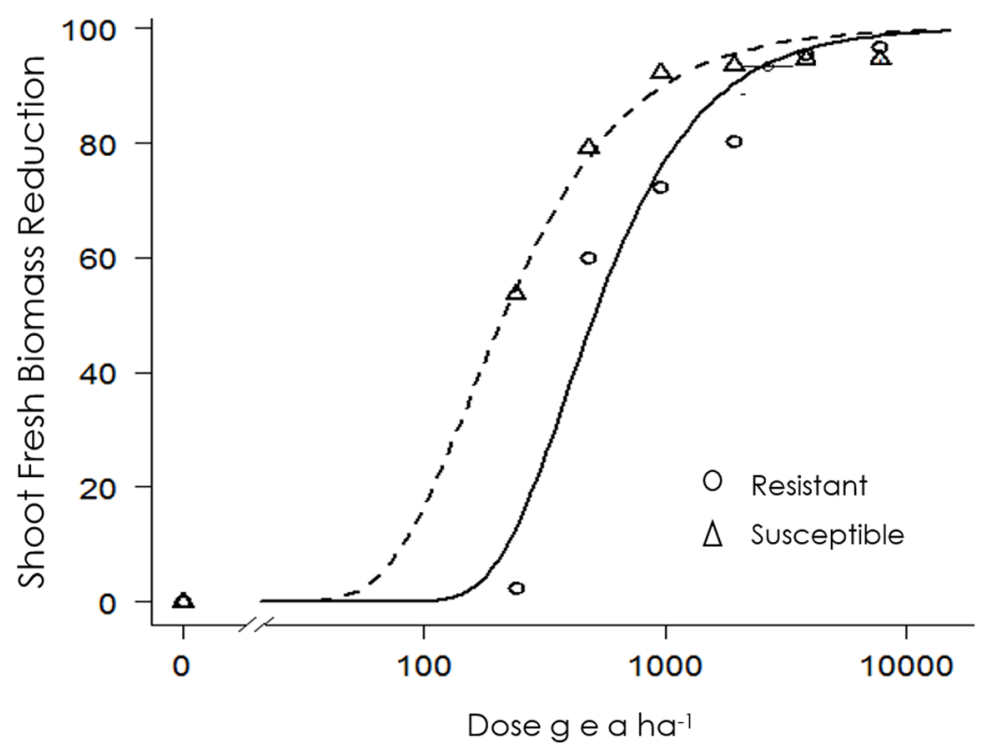

Figure 1. Shoot freshbiomass reduction of sourgrass 21 days after the application (DAA), for both biotypes (Oresistant $\Delta$ susceptible) at different glyphosate doses. ${ }^{*}$ Equations: $Y=$ $-2.56+\left\{(90.72+2.56)\left[1+(x / 394.24)^{-2.12}\right]\right\}$ and $Y=-0.01+\left\{(95.10-0.01)\left[1+(x / 160.22)^{-1.47}\right]\right\}$ for $R$ and $\mathrm{S}$ biotypes.

Table 1. Mean values of the distance between vascular bundles distances, parenchymal thickness and xylem/ phloem relation of glyphosate resistant and susceptible biotypesof sourgrass.

\begin{tabular}{ccccc}
\hline Biotype & Vascular bundles distance $(\mu \mathrm{m})$ & Parenchymal thickness $(\mu \mathrm{m})$ & Xylem/phloem relation \\
\hline Resistant & $116,50 \mathrm{~b}$ & $67,18 \mathrm{~b}$ & $2,32 \mathrm{a}$ \\
Susceptible & $130,27 \mathrm{a}$ & $74,93 \mathrm{a}$ & $2,05 \mathrm{~b}$ \\
\hline Means followed by different lefters in the columns are significantly different by Tukey's test at 5\% probability. &
\end{tabular}

The reduced thickness of the parenchyma in the resistant biotype is related with less intercellular spaces decreasing the amount of circulating $\mathrm{CO}_{2}$ to be used in the photosynthesis. The considerable amount of gases atthe mesophyll, in the case of the resistant biotype, can provide higher pressure onthe leaf blade, obstructing the water and glyphosate flow from one cell to another. Therefore, the susceptible $D$. insularis biotype might present a faster transport from cell to cell. These factors corroborate the fact that the resistance of $D$. insularis to the herbicide also occurs due to differences in the translocation (Galvani et al., 2012).Also is possible that the thickness of leaves in this casehad no effect on the glyphosate differential sensitivity between biotypes, being the glyphosate tolerance major due by differential penetration or others translocation patterns (Monquero et al., 2004).

Besides, the vascular bundle distance and the xylem/phloem relation showed statistical differences between both biotypes (Table 1).Leaves with nearbybundles have a lower hydraulic resistance and higher photosynthetic rates, as in this case, resistant plants (Table 1 and Figure 2). The proximity of the leaf vascular bundles has an important impact on gas exchange rates(Taiz\& Zeiger 2013). Indeed, the resistant biotype may have a higher translocation of assimilates, greater distribution of water and herbicides, which may contribute into a rapid metabolism of the herbicide in the resistant biotype, as it was previously observed (Carvalho et al., 2012).The possible higher photosynthetic rates in resistant plants, be able to explain their faster development compared with susceptible (Melo, 2011). These morphological differences appear to impact not also the herbicide tolerance, but also, the development of the plants, that will also play an important role in herbicide efficacy. 


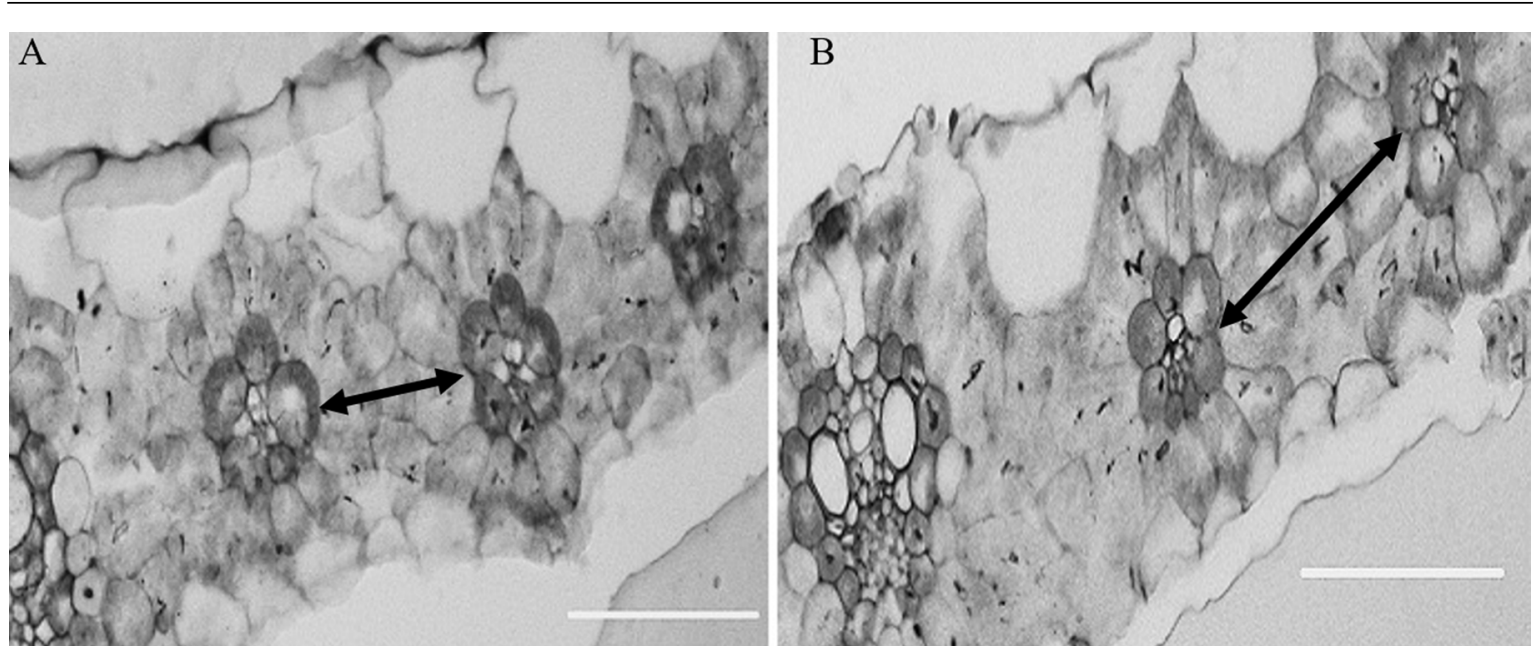

Figure 2. Cross section of sourgrass leaves. A) Resistant biotype to glyphosate. B) Susceptible biotype to glyphosate. /=100 $\mu$ m. The arrows indicates the distances between the vascular bundles. The images are in the same scale.

The xylem/phloem ratio greater in the resistant biotype shows a larger area of the xylem or a smaller area of the phloem compared to the susceptible biotypes. The glyphosate translocates via phloem, thus, its translocation could be higher in the susceptible biotype.

\section{Stomata}

Although D. insularis presents stomata on both sides (amphistomatic leaves), in the analysis of scanning electron microscopy was observed that the number of stomata was greater on the abaxial leaf surface (Table 2, Figure 3), corroborating the study of Machado et al., (2006).

Table 2. Mean values of stomatal index, stomatal density and density of trichomes of glyphosate resistant and susceptible sourgrass biotypes in three different vegetative stages.

\begin{tabular}{|c|c|c|c|c|c|c|}
\hline \multirow{2}{*}{$\begin{array}{l}\text { Biotype } \\
\text { Leaf surface }\end{array}$} & \multicolumn{2}{|c|}{ Stomatal index (\%) } & \multicolumn{2}{|c|}{$\begin{array}{l}\text { Stomatal density } \\
\text { (stomata } \mathrm{mm}^{-2} \text { ) }\end{array}$} & \multicolumn{2}{|c|}{$\begin{array}{c}\text { Density of trichomes } \\
\text { (trichomes } \mathrm{mm}^{-2} \text { ) }\end{array}$} \\
\hline & Adaxial & Abaxial & Adaxial & Abaxial & Adaxial $^{1}$ & Abaxial \\
\hline S (V4) & $15 a$ & $20 \mathrm{c}$ & $64 a$ & $126 \mathrm{c}$ & $4 a b$ & $0 \mathrm{c}$ \\
\hline$S(V 6)$ & $14 a$ & $26 a$ & 62 a & $264 a$ & $14 \mathrm{a}$ & $106 a$ \\
\hline$S(R)$ & $16 a$ & $21 \mathrm{bc}$ & $64 a$ & $142 \mathrm{C}$ & $0 \mathrm{~b}$ & $2 c$ \\
\hline R (V4) & $15 a$ & $26 a$ & 78 a & $134 \mathrm{C}$ & $0 \mathrm{~b}$ & $2 c$ \\
\hline$R(V 6)$ & $15 a$ & $24 a b$ & 66 a & $180 \mathrm{~b}$ & $14 a$ & $38 \mathrm{~b}$ \\
\hline$R(R)$ & $11 \mathrm{a}$ & $18 \mathrm{c}$ & $30 \mathrm{~b}$ & $134 \mathrm{C}$ & $0 \mathrm{~b}$ & $12 c$ \\
\hline
\end{tabular}

The guard cells of stomata showed up in the form of dumbbells with interstomatal cells, and the last ones presented slightly concave edges, with stomata located in rows along the veins, as typical for the structure in species of Poaceae. In this study, plants showed a higher stomatal density compared with the values observed by others (Machado et al., 2006). The stomata and the leaf surface showed large amount of epicuticular wax deposition, what can be associated with the slow absorption of the herbicide observed in previous studies (Figure 3) (Carvalho et al., 2012).
The stomatal index on adaxial surface did not vary with the growth stage of the plant or with the biotype (Table 2). For the abaxial surface, it was noted that the number of stomata per area was higher in leaves with more developed stages of growth for the susceptible biotype. The resistant biotype had decreased numbers of stomata when the leafcame from regrowth (as a brunch) while the susceptible biotype kept the same number (Table 2). Additionally, it was noted that there wasa decreasein these structures in the leavesfrom regrowth, on the adaxial surface for the resistant biotype. On the other hand, for the 

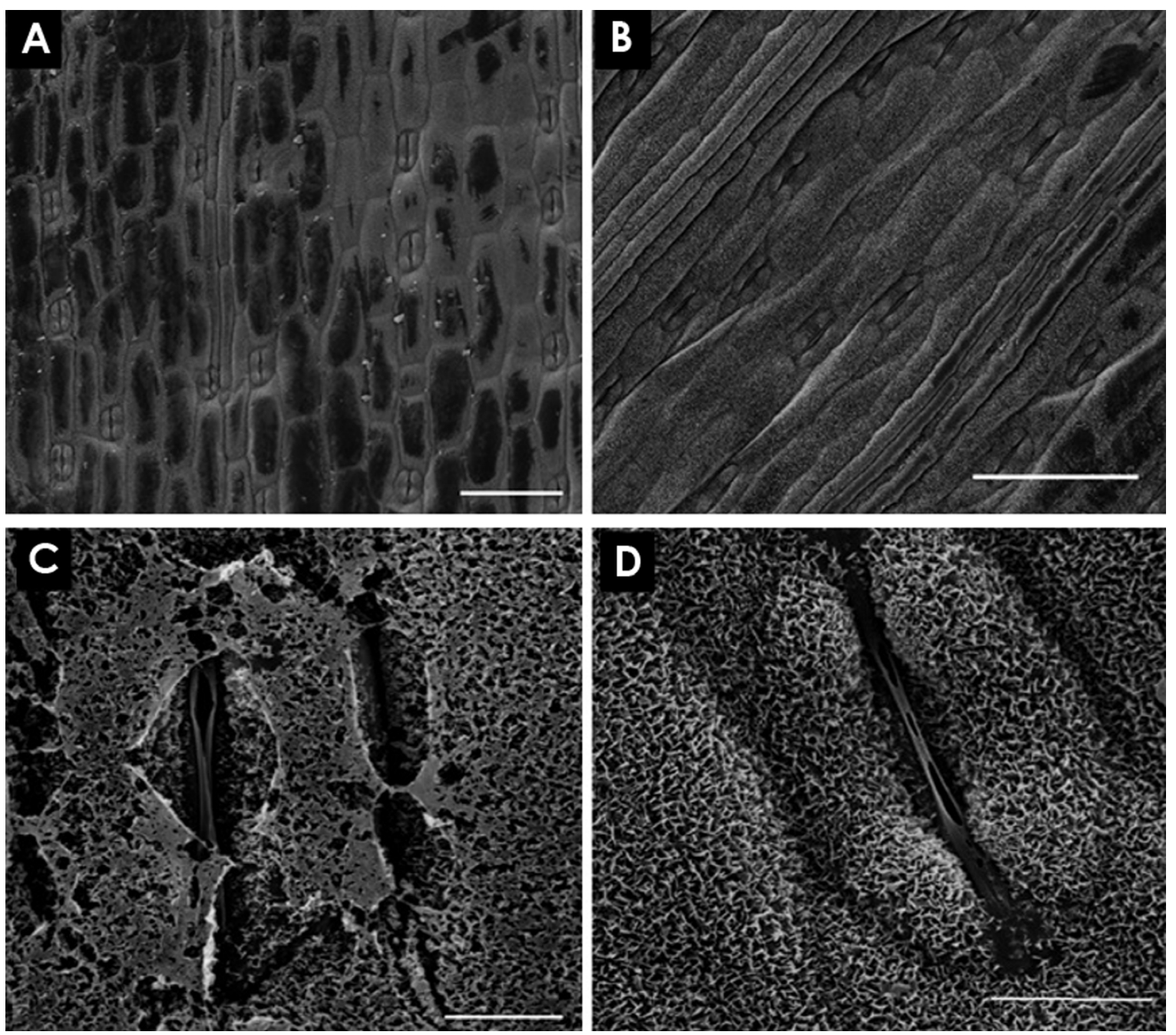

Figure 3. Scanning electron microscopy of the leaf epidermis of sourgrass. A) Adaxial surface of the resistant biotype to glyphosate. B) Adaxial surface of the susceptible biotype to glyphosate. C) Stomata of the resistant biotype to glyphosate. D) Stomata of the susceptible biotype to glyphosate. / $100 \mu \mathrm{m}$.

abaxial surface, the stomatal density increased with the D. insularis development.

Similar results were demonstrated inBrachiaria decumbens, Ambrosia artemisiifolia, Echinochloa crus-galliand Setaria viridis plants, which exhibited stomata on both leaf surfaces (Grangeot et al., 2006; Sanyal et al., 2006; Marques et al., 2012). ComparingbothD. insularis biotypes, the presence of stomata was higher in the most developed plants of the susceptible biotype.

The presence of more stomata in susceptible plants is also an indication of faster uptake of the herbicide in this biotype. It's know that herbicide absorption via stomata is very limited anddepends on the surfactants usage, but the cuticle on the guard cells is generally thinner and more permeable due to polar substances and are likely a route to herbicide
penetration(Schreiber, 2005; Schönherr, 2006). Trichomes

The presence of trichomes can significantly stimulatesthe retention, and subsequently, the product absorption (Schönherr, 2006). Most often, the increased presence of trichomes also reduces the amount of herbicide reaching the epidermis due to retaining droplets, but these factors are still not well understood (Procópio et al., 2003; Galvani et al., 2012; Marques et al., 2012).In terms of the presence of trichomes in both biotypes, it was observed that the development of $D$. insulariselevates the presence of these structures, which can be observed for both biotypes in both leaf surfaces, as was detected by Marques et al., (2012) and Sanyal et al (2006) in Brachiaria decumbens and in Echinochloa crus-galliand Setaria viridis (Table 2, Figure 4). 
The absence of trichomes in D. insularis resistant plants in early stages of development reinforces the concept of the glyphosate application efficacyin less developed stages. In more advanced stages of leaf maturity, it was observed that the abaxial surface of the susceptible biotype presented more trichomes compared to the resistant biotypeas was reported in E.crus-galli(Table 2) (Sanyal et al., 2006). The abundance of trichomes in susceptible plants in the abaxial leaf surface may be related to the differential absorption (less than 16\%) of the resistant plants in the first twelve hours compared to susceptible (Carvalho et al., 2012).

Other authors have found that the presence of trichomes influence on liquid absorption. The presence of trichomes and aquaporins were essential in the absorption of water in Tillandsia ionantha plants (Ohrui et al., 2007; Maurel, 2001). Also the presence of trichomes facilitates the absorption of water and its influx in the mesophyll of leaves (Grammatikopoulos\& Manetas, 1994). Some authors reported that the uptake by trichomes depends on its cutinization, which prevents the entry of the solutions in the cell (Burrows et al. 2013). Despite being a complex issue, the absorption of solutions via trichomes is already well documented (Fernández\& Brown, 2013; Fernández et al.,2014). Trichomes without cuticle emerging from cells with large amounts of wax in susceptible plantsplus the large size of the adaxial epidermis, could maximize the speed and amount of absorption of glyphosate in the susceptible biotype (Figure 4).
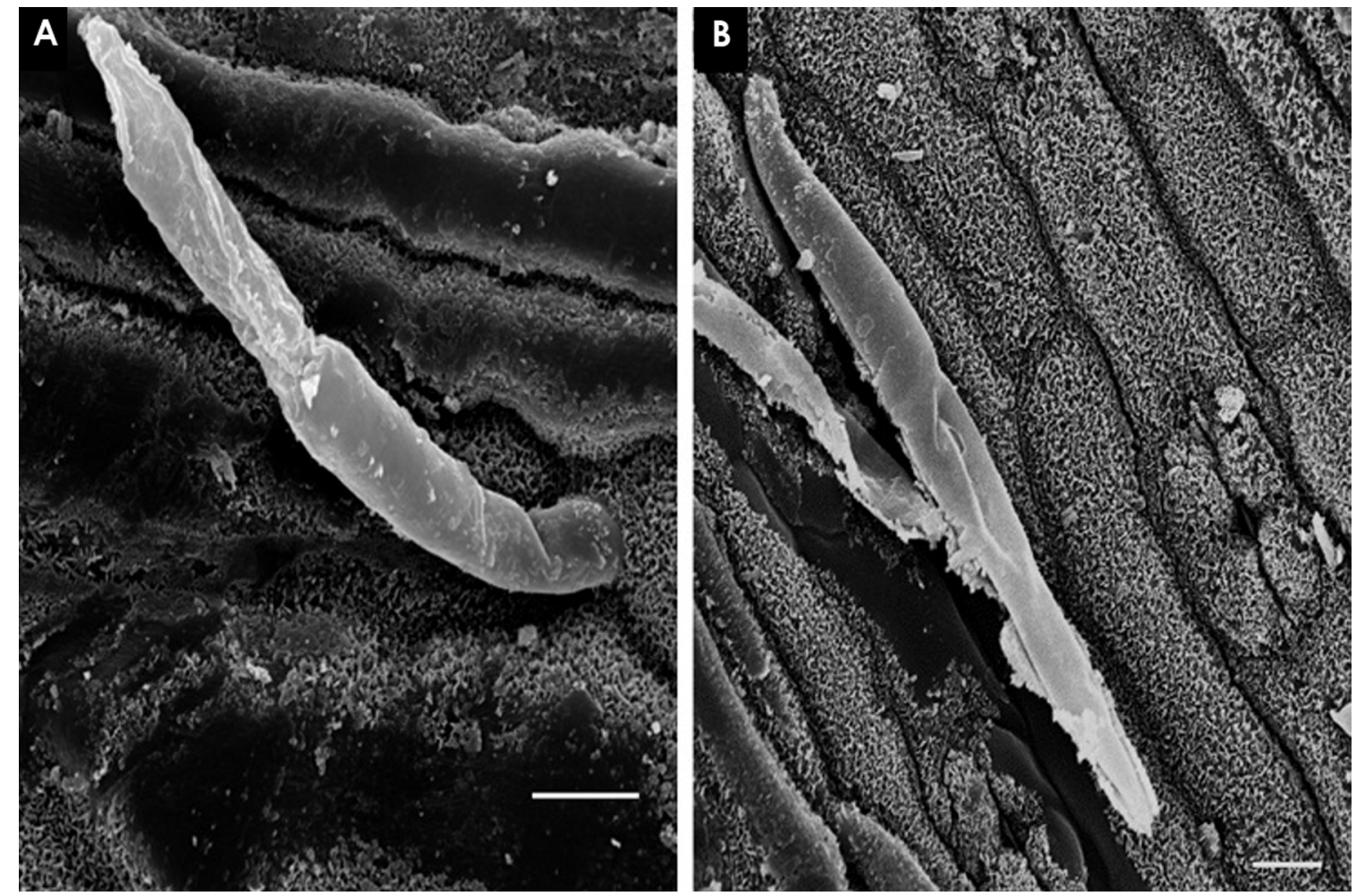

figure 4. Scanning electron microscopy of the sourgrass leaf epidermis. A) Trichome of resistant plant to glyphosate. B) Trichome of susceptible plant to glyphosate. $/=100 \mu \mathrm{m}$.

The epicuticular surface of Neonotonia wightii and Clitoria ternatea presentedhigher wax coverage compared toAmaranthus hybridus, which led topoor herbicide penetration and explains the high glyphosate tolerance (CruzHipólito et al., 2011). In addition, Bidens bipinnata and Sorghum halepenseshowed higher leaf wax content and less absorption compared to Desmodium tortuosum(Singh et al., 2011).
Implications

In Italian ryegrass plants, the adaxial surface was less wettable and retained less fluid compared with the abaxial surface, which can occurs in D. insularis plants. Still, two-thirds of the fluid were retained in the abaxial surfaces of leaves. Yet as it is a grass, when a new leaf develops, the topsheet leaf may twist and expose the abaxial surface to the applied product 
(Schott et al., 1991).

Indeed, this differential absorption was also noted in Lolium multiflorum and may be responsible for differential absorption of glyphosate in D. insularis plants, which needs to be further investigated (Michitte et al., 2007). The differential tolerance is also influenced by the presence of stomata and trichomes in cultivated plants, such as sugarcane, which present higher phytotoxicity to the herbicide due to the abundance of these structures (Ferreira et al., 2007).

The water absorption via trichomes was also demonstrated in plants adapted to dry conditions, such as bromeliads. Although it occurs with low frequency, this absorption mechanism may become important for $D$. insularis (Figure 3), keeping in mind that it absorbs less than half of the glyphosate applied after 96 hours (Carvalho et al., 2012).

Other physiological and anatomical resistance associations were described by Satichivi et al., (2000) observing large glyphosate quantities moving to tissues above the treated leaf in Abutilon theophrasti and Setaria faberi plants. Also, glyphosate translocation in Helianthus annus did not differ and the herbicide remained in the treated leaves between Orobanche cumana-infested and non-infested plants (Diaz-Sanchez et al., 2002).Susceptible plants treated with glyphosate significantly affectedthe unexpanded leaves and the apical meristem but did not influence leaf absorption or translocation in resistant population (Yanniccari et al., 2012).

The decrease in the number of trichomes on leaves (originated from regrowth) along with the presence of fewer stomata shows that management techniques, such as using a trimmer prior to herbicide application, could be an important tool in resistance management in cases where the plants could present a high vegetative stage. Studies highlight the grubbing technique as a viable step when applying inhibitors of Acetyl-Coenzyme a Carboxylase to improve them effect, in which the plants are in a high physiological and leaf maturity (Correia et al., 2015).

\section{Conclusions}

Digitaria insularisshowed differences in stomata, vascular bundle, parenchyma, xylem/ phloem relation and trichomes that caninfluence the different glyphosate efficacy between biotypes.The herbicide resistance caused by differential absorption is complex and still need further studies.

\section{Acknowledgments}

The authors would like to thank Francisco Tanaka for his support and ideas, and FAPESP/ CNPq for the researcher's scholarships.

\section{References}

Burrows, G.E., White, R.G., Harper, J.D.,Heady, R.D, Stanton, R.A., Zhu, X., Wu, H., Lemerle, D. 2013. Intrusive trichome bases in the leaves of silverleaf nightshade (Solanum elaeagnifolium, Solanaceae) do not facilitate fluorescent tracer uptake. American Journal of Botany 100: 23072317.

Carvalho. L.B., Alves, P.L.C.A., Bianco, S. 2013. Sourgrass densities affecting the initial growth and macronutrient contente of Coffee plants. Planta Daninha 31: 109-115.

Carvalho, L.B., Alves P.L., González-Torralva, F., Cruz-Hipolito, H.E., Rojano-Delgado, A.M.,De Prado, R., Gil-Humanes, J., Barro, F., de Castro, M.D. 2012.Pool of resistance Mechanisms to Glyphosate in Digitaria insularis. Journal of Agricultural and Food Chemistry 60: 615-622.

Carvalho, L.B.,Cruz-Hipolito, H., GonzálezTorralva, F., Alves, P.L.C.A., Christoffoleti, P.J., De Prado, R. 2011.Detection of sourgrass (Digitaria insularis) biotypes resistant to glyphosate in Brazil. Weed Science 59: 171-176.

Correia, N.M., Acra, L.T., Balieiro, G. 2015. Chemical controlo $f$ diferente Digitaria insularis populations and management of glyphosateresistant population. Planta Daninha 33: 93-101.

Correia, N.M., Leite, G.J., Garcia, L.D.2010. Response of differentDigitaria insularis populations to glyphosate. Planta Daninha 28: 769-776.

Cruz-Hipolito, H., Rojano-Delgado, A., Dominguez-Valenzuela, J., Heredia, A., Castro, M, Prado, R. 2011.Glyphosate tolerance by Clitoria ternatea and Neonotonia wightii plants involves differential absorption and translocation of the herbicide. Plant Soil 347: 221-230.

Diaz-Sanchez, J., Lopez-Martinez, N., LopezGranados, F., De Prado, R., Garcia-Torres, L. 2002. Absorption, translocation, and fate of herbicides in Orobanche cumana-suuflower system. 
Pesticide Biochemistry and Physiology 74: 9-15.

Fernández, V., Brow, P.H. 2014. From plant surface to plant metabolism: the uncertain fate of foliarapplied nutrients. Frontiers in Plant Science 4: 289.

Ferreira, E.A., Ventrella, M.C., Santos, J.B., Barbosa, M.H.P., Silva, A.A., Procópio, S.O., Silva, E.A.M. 2007.Leaf blade quantitative anatomy of sugarcane cultivars and clones. Planta Daninha 25: 25-34.

Galvani, J., Rizzardi, M.A., Carneiro, C.M., Bianchi, M.A. 2012.Leaf anatomy of Lolium multiflorum sensitive and resistant to glyphosate. Planta Daninha 30: 407-413.

Grammatikopoulos,G., Manetas, Y. 1994. Direct absorption of water by hairy leaves of Phlomis fruticosa and its contribution to drought avoidance. Canadian Journal of Botany72:1805-1811.

Grangeot, M., Chauvel, B., Gauvrit, C. 2006. Spray retention, foliar uptake and translocation of glufosinate and glyphosate in Ambrosia artemisiifolia. Weed Research 46:152-162.

Hess, F.D., Falk, R.H., 1990. Herbicide deposition on leaf surfaces. Weed Science 38:280-288.

Knezevic, S.Z., Streibig JC, Ritz, S. 2007. Utilizing R software package for dose-response studies: the concept and data analysis. Weed Technology 21: 840-848.

Machado, A.F.L., Ferreira, L.R., Ferreira, F.A., Fialho, C.M.T., Tuffi Santos, L.D., Machado, M.S. 2006. Growth analysis of Digitaria insularis. Planta Daninha 24: 641-647.

Marques, R.P., Rodella, R.A., Martins, D. 2012. Characteristics of the leaf anatomy of Surinam grass and Alexandergrass related to sensitivity to herbicides. Planta Daninha 30: 809-816.

Maurel, C. Maarten, J.C 2001. Aquaporins. A molecular entry into plant water relations. Plant physiolog. 125: 135-138

Melo, M.S.C. 2011.Alternativa de controle, acúmulo de shiquimato e curva de crescimento do capim-amargoso (Digitaria insularis) suscetivel e resistente ao glyphosate. 74f. (Dissertação de mestrado) - Universidade de São Paulo, Piracicaba, Brasil.

Michette, P., De Prado, R., Espinoza, N., RuizSantaella, J.P., Grauvit, C. 2007.Mechanisms of resistance to glyphosate in a Ryegrass (Lolium multiflorum) biotype from Chile. Weed Science 55: 435-440.

Monquero, PA., Christoffoleti, P.J., Matas, J.A., Heredia, A. 2004. Caracterização da superfície foliar e das ceras epicuticulares em Commelina benghalensis, Ipomoea grandifolia e Amaranthus hybridus. Planta Daninha 22: 203-210.

Ohrui, T., Nobira, H., Sakata, Y., Taji, T., Yamamoto, C., Nishida, K., Yamakawa, T., Sasuga, Y., Yaguchi, Y., Takenaga, H., Tanaka, S. 2007. Foliar trichome and aquaporin aided water uptake in droughtresistant epiphyte Tillandsia ionantha Planchon. Planta 227: 47-56.

Procópio, S.O., Ferreira, E.A.,Silva, E.A.M.,Silva, A.A., Rufino, R.J.N., Santos, J.B.,2003. Leaf anatomical studies in weed species widely common in Brazil. III - Galinsoga parviflora, Crotalaria incana, Conyza bonariensis and Ipomoea cairica. Planta Daninha 21: 1-9.

Sanyal,D., Bhowmik, P.C., Reddy, K.N. 2006. Influence of leaf surface micromorphology, wax content, and surfactant on primisulfuron droplet spread on barnyardgrass (Echinochloa crus-galli) and green foxtail (Setaria viridis). Weed Science 54: 627-633.

Satichivi, N.M., Wax, L.M., Stoller, E.W., Briskin, D.P. 2000. Absorption and translocation of glyphosate isopropylamine and trimethysulfonium salts in Abutilon theophrasti and Setaria faberi. Weed Science 48: 675-679.

Schreiber, L. 2005. Polar paths of diffusion across plant cuticles: new evidence for an old hypothesis. Annals of Botany 95: 1069-1073.

Singh, M., Sharma, S.D., Ramirez, A.H.M., Jhala, A.J. 2011 . Glyphosate Efficacy, Absorption, and Translocation in Selected Four Weed Species Common to Florida Citrus. HortTechnology 21: 599-605.

Schonherr, J. 2006. Characterization of aqueous pores in plant cuticles and permeation of ionic solutes. Journal of Experimental Botany 57: 2.4712.491

Schott, J.J., Dufour, J.L., Gauvrit, C. 1991. Effects of adjuvants on herbicidal action. III - Effects of petroleum and rapeseed oils on diclofopmethyl action on ryegrass. Agronomie 11: 27-34.

Taiz, L., Zeiger, E. 2013. Plant physiology. Sinaver Associates, Sunderland, MA. 918 p.

Vila-Aiub, M.M., Balbi, M.C., Distéfano, A.J., Fernández, L., Hopp, E., YU, Q., Powles, S.B. 2011. Glyphosate resistance in perennial Sorghum halepense, endowed by reduced glyphosate translocation and leaf uptake. Pest Management Science 68: 430-436.

Yanniccari, M., Istilart, C., Giménez, D.O., Castro, A.M. 2012. Effects of glyphosate on the movement of assimilates of two Lolium perenne L. populations with differential herbicide sensitivity. Environmentaland Experimental Botany 82: 1419 